PREGLEDNI RAD

UDK: 659.4(497.5:4)

Prof. dr. sc. Ana Tkalac Verčič

\title{
TRENDOVI U RAZVOJU ODNOSA S JAVNOŠĆU: USPOREDBA PROCJENA HRVATSKIH I EUROPSKIH KOMUNIKACIJSKIH STRUČNJAKA
}

\author{
TRENDS IN PUBLIC RELATIONS DEVELOPMENT: \\ COMPARING CROATIAN AND EUROPEAN \\ COMMUNICATION EXPERTS ESTIMATIONS
}

\begin{abstract}
SAŽETAK: Odnosi s javnošću, kao akademska disciplina, ali i kao poslovna funkcija, pod velikim su utjecajem kulture i političkoga sustava unutar kojega djeluju (Sriramesh i White, 1992.). Za komunikacijske stručnjake važno je pitanje - razlikuju li se osnovni principi primjene odnosa s javnošću od zemlje do zemlje? Tijekom posljednjih desetak godina broj znanstvenih istraživanja unutar odnosa s javnošću u Europi raste i daje sve veći broj teorija i empirijskih uvida u praksu koji ukazuju na razlike u načinu primjene odnosa s javnošću u različitim zemljama. Upravo stoga cilj ovoga rada bio je provjeriti postoji li značajna razlika u procjeni važnosti ključnih problemskih pitanja među hrvatskim i europskim stručnjacima za odnose s javnošću? Rezultati istraživanja ukazuju da se procjena važnosti hrvatskih stručnjaka donekle razlikuje od procjene europskih komunikatora. Takvi rezultati potvrđuju tezu o lokalnoj specifičnosti odnosa s javnošću i naglašavaju važnost lokalnoga razvoja znanja i vještina, uz korištenje globalnih teorija i koncepata.
\end{abstract}

KLJUČNE RIJEČI: odnosi s javnošću u Hrvatskoj, odnosi s javnošću u Europi, trendovi u odnosima s javnošću, Europski komunikacijski monitor.

\begin{abstract}
Public relations, both, as an academic discipline, and a business function, is under the influence of culture and the political system within which it operates (Sriramesh \& White, 1992). For communication experts therefore the question is clear - are there significant differences in the way public relations is practiced in various countries? During the last decade the number of scientific studies focused on public relations in Europe is significantly increasing and consequently the number of theories and empirical insights into practice is growing. Therefore, the aim of this paper was to explore potential differences in how key public relations issues are perceived among Croatian and other European communication experts. Results of the analysis show that Croatian public relations specialists
\end{abstract}

Prof. dr. sc. Ana Tkalac Verčič, redovita profesorica, Ekonomski fakultet - Zagreb, Trg J. F. Kennedyja 6, 10000 Zagreb, telefon: +385 1238 3333, e-mail: atkalac@efzg.hr 
differ somewhat from their European colleagues in their estimation of key communication issues. These results confirm the thesis that public relations is a highly local business function, and add to the importance of local development of knowledge and skills, while using global theories and concepts.

KEY WORDS: Public relations in Croatia, public relations in Europe, trends in public relations, European communication monitor.

\section{UVOD}

Svugdje u Europi komunikacijski stručnjaci imaju sve veći utjecaj i sve višu razinu formalnoga položaja u organizacijama. Na području odnosa s javnošću razvijaju se novi obrasci donošenja odluka i novi načini upravljanja. S druge strane, komunikacijskim praktičarima još uvijek nedostaju informacije i znanja o ključnim poslovnim područjima. Pojmovi poput „korporativnih komunikacija“ i „strateških komunikacija“ postaju popularniji od „odnosa s javnošću“, pojma sa sve lošijom reputacijom u brojnim zemljama (Zerfass, Verhoeven, Tench, Moreno i Verčič, 2011.). Odnosi s javnošću pod utjecajem su kulture i političkoga sustava unutar kojega djeluju (Sriramesh i White, 1992.). Trajno pitanje za komunikacijske stručnjake stoga je - hoće li se odnosi s javnošću razlikovati od zemlje do zemlje, obzirom na političke i kulturološke okolnosti. Ako su razlike među kulturama velike, nije moguće razviti opće normativne teorije o tome što odnosi s javnošću čine i kako ih je potrebno primjenjivati (Verčič, Grunig i Grunig, 1996.).

U proučavanju odnosa s javnošću važno je odrediti kolike su razlike među različitim zemljama kada je riječ o primjeni komunikacijske funkcije. Dodatno, kakav je položaj odnosa s javnošću kao mlade profesije u Hrvatskoj? Postoje li značajne razlike u načinu na koji hrvatski praktičari ocjenjuju ključne odrednice profesije? Iako je tijekom posljednjih desetak godina značajno povećan broj istraživanja odnosa s javnošću u Europi, cijeli niz zapreka poput različitih jezika, akademskih kultura, nepostojanja pan-Europskih udruženja ili baza podataka ograničilo je mogućnosti izvođenja jedinstvenih zaključaka o univerzalnoj, europskoj komunikacijskoj praksi (Moreno, Zerfass, Tench, Verčič i Verhoeven, 2009.).

Europske, usporedne studije u odnosima s javnošću još su relativno rijetke i uglavnom ograničene na male, prigodne uzorke (Golob i Bartlett, 2007.; Coombs, Holladay, Hasenauer i Signitzer, 1994.). Jedino sustavno i akademski rigorozno longitudinalno istraživanje odnosa s javnošću u Europi započelo je 1998. godine kao istraživački projekt nazvan EBOK (European Public Relations Body of Knowledge project; van Ruler i Verčič, 2008.) te od 2007. godine kao Europski komunikacijski monitor (European Communication Monitor) koji se provodi godišnje među više od 2.000 praktičara iz 40 zemalja (Zerfass, Tench, Verčič, Verhoeven i Moreno, 2014.).

Europski komunikacijski monitor, nakon desetljeća provođenja, omogućava usporedbu prakse odnosa s javnošću i komunikacijskog menadžmenta odnosno određivanje ključnih problemskih pitanja odnosa s javnošću u različitim zemljama Europe. ECM se od samoga početka provodi i u Hrvatskoj, na uzorku od 662 ispitanika u proteklih 10 godina. Cilj ovoga rada je analizom izdvojenih podataka među hrvatskim stručnjacima te usporedbom s ukupnim, europskim rezultatima, definirati trendove razvoja područja u Hrvatskoj i smjestiti profesiju odnosa s javnošću u europski kontekst. Istraživačko pitanje rada stoga je 
- odrediti postoji li značajna razlika u procjeni važnosti ključnih problemskih pitanja među hrvatskim i europskim stručnjacima za odnose s javnošću?

\section{TEORIJSKI OKVIR}

\subsection{Odnosi s javnošću u Europi i Hrvatskoj}

Suvremena praksa odnosa s javnošću (u svim oblicima primjene poput komunikacijskog menadžmenta ili korporativnih komunikacija) stara je stotinjak godina, no odnosi s javnošću kao znanstvena disciplina puno su mlađi (Verčič, Verhoeven i Zerfass, 2014.). S druge strane, razvoj teorije i znanosti na području odnosa s javnošću ima relativno kratku povijest od oko tri desetljeća (Grunig, 1992.). Većina dosadašnje teorijske analize i znanstvenih istraživanja dolazi iz Sjedinjenih Američkih Država, tako da ne iznenađuje da se odnosi s javnošću smatraju znakovito, američkim «izumom». Carlson je 1968. pišući za međunarodnu enciklopediju društvenih znanosti (International Encyclopedia of the Social Sciences) naveo da su odnosi s javnošću «dijete Amerike 20. stoljeća». Tedlow (1979., str. 12.) je odnose s javnošću definirao kao «...rezultat američkoga političkog i komercijalnog razvitka». Wilcox, Ault i Agee (1989.) su odnose s javnošću također proglasili američkim fenomenom, pri čemu su tvrdili da se američki principi poslovanja primjenjuju diljem cijeloga svijeta. Nessmann (1995.) se međutim ne slaže i tvrdi kako američke definicije nisu prihvaćene u Europi. Točnije, postoje značajne razlike u načinu primjene odnosa s javnošću od zemlje do zemlje. Nessmann dodatno zaključuje da u Europi odnosi s javnošću još uvijek nisu prihvaćeni kao dio menadžmenta. Naravno, ovi zaključci stari su više od dvadeset godina, pa je zanimljivo pitanje - je li se pozicija odnosa s javnošću do danas izmijenila.

Suvremena povijest različitih europskih država značajno je odredila način razvoja komunikacijskih disciplina. U zapadnoj Europi odnosi s javnošću razvijali su se slično kao i u Sjedinjenim Američkim Državama u 19. stoljeću. Carl Hundhausen prvi je u Njemačkoj uveo pojam odnosa s javnošću 1937. kada je napisao članak pod tim imenom. Na njemačkome je govornom području ujedno bilo mnogo pokušaja germanizacije engleskoga pojma Public relations ili kratice PR, no niti jedan nije do kraja uspio. Unatoč tome što se u međuvremenu na njemačkome govornom području razvio pojam Öffentlichkeitsarbeit, praktičari uglavnom i dalje koriste američku kraticom PR. Slični terminološki problemi prate odnose s javnošću svugdje u svijetu, pa tako i u Hrvatskoj (Tkalac, Verčič, 2016.).

McManus (1994.) navodi značajne razlike među britanskim i austrijskim praktičarima odnosa s javnošću. Čak 88 posto britanskih komunikacijskih stručnjaka slaže se s Grunigovom i Huntovom definicijom odnosa s javnošću, dok je među austrijskim praktičarima taj postotak samo 66. Dodatno, 8 posto britanskih praktičara ne slaže se s navedenim pristupom odnosima s javnošću, dok je među Austrijancima taj postotak čak 32.

U Hrvatskoj sustavno znanstveno istraživanje i obrazovanje na području odnosa s javnošću nije postojalo prije 1989. g. (Hajoš, 2002.). Institucionalizacija odnosno uvođenje odnosa s javnošću u akademske institucije, sve veći broj diplomskih, magistarskih, a odnedavno i doktorskih radova te osnivanje udruženja, uzeli su maha tek u drugoj polovini devedesetih. U curriculumu kolegija Promocija na katedri za marketing Ekonomskog fakulteta u Zagrebu od ranih devedesetih bila je uključena i tematska cjelina pod nazivom «odnosi s javnošću». 
Međutim, obuhvat spomenutoga curriculuma bio je dosta uzak kada se radilo o odnosima s javnošću i analizirao ih je isključivo kao dio promotivnog miksa (Tkalac, 2003.).

$\mathrm{U}$ isto vrijeme (tijekom devedesetih) razvoj profesije van akademskih krugova dobio je veliki zamah. Iako su prve agencije postojale već i ranije, u drugoj polovini devedesetih osniva se veći broj agencija za odnose s javnošću koje djeluju samostalno (van okrilja propagandnih agencija). Najveći zamah u razvoju i djelovanju agencija odvijao se tijekom početka novoga stoljeća, kada su nastajale agencije koje danas predvode tržište. Prometi agencija u tim su danima bili veći nego danas kada je financijska kriza dovela do vidljive stagnacije na tržištu (Petrović, Tepeš i Žigić, 2014.). Kao reakcija na sve veću potražnju za stručnjacima ove profesije uspostavljaju se društva za odnose s javnošću, prvo 1994. Hrvatsko društvo za odnose s javnošću (ime je 1998. promijenjeno u Hrvatska udruga za odnose s javnošću) i 1999. Strukovna udruga za odnose s javnošću (Tkalac, 2003.). Hrvatski Oglasni Zbor također je među svoje domove uveo i dom odnosa s javnošću kao reakciju na sve veći broj agencija i stručnjaka s toga područja. Rezultat opisanih trendova dovodi do sve veće potražnje za obrazovanim stručnjacima s područja odnosa s javnošću, no obrazovne institucije ne prate dovoljnom brzinom spomenutu potrebu (Tkalac, 2003.).

Situacija u odnosima s javnošću u Hrvatskoj danas je značajno bolja. Odnosi s javnošću uvedeni su na svim obrazovnim razinama. Programi cjeloživotnoga obrazovanja i stručnih usavršavanja, kao najprilagodljiviji, prvi su počeli nuditi sadržaje koji bi mogli zadovoljiti zahtjeve tržišta. Iako su u prošlosti takvi obrazovni programi često odnose $\mathrm{s}$ javnošću svodili na glasnogovorništvo, danas se češće prihvaćaju suvremeni oblici teorije odnosa s javnošću i programi postaju opširniji. Odnosi s javnošću na akademskoj razini još zaostaju za stručnim obrazovanjem. Kao kolegij nude se na nekoliko sveučilišnih institucija u Zagrebu, Osijeku, Dubrovniku i Zadru. Kao usmjerenje postoje na Fakultetu političkih znanosti Sveučilišta u Zagrebu te na sveučilištima u Dubrovniku i Osijeku. Dodatno, sve više fakulteta radi na uvođenju ne samo preddiplomskoga i diplomskoga usmjerenja, nego i dogradnje doktorskim studijem (Tkalac, Verčič, 2016.).

Hrvatska udruga za odnose s javnošću postala je središnje mjesto unapređenja prakse. Kako bi se unaprijedila kvaliteta struke, udruga je između ostaloga provela i četiri sveobuhvatna istraživanja o stanju struke u Hrvatskoj. Istraživanja su provedena 2003., 2006., 2009. i 2014. i bila su usmjerena na osnovne probleme hrvatskih komunikacijskih stručnjaka. U 2004., u Hrvatskoj se odnosima s javnošću bavilo negdje između 1.000 i 1.500 profesionalaca uključenih u različite vrste komunikacijske prakse (Hajoš i Tkalac, 2004., str. 85.). Jedan od razloga za tako velik broj bila je relativno nejasna definicija područja odnosa s javnošću. U to je vrijeme bilo jednostavno postati stručnjak za odnose s javnošću - dovoljno je bilo proglasiti se takvim. Naravno, obrazovni profili komunikacijskih stručnjaka bili su u to vrijeme vrlo različiti. Većina ih je u odnose s javnošću došla iz novinarstva (obrazovanje u odnosima s javnošću nije bilo niti moguće, jer se tada nije nudilo na akademskoj razini). Danas, Hrvatska udruga za odnose s javnošću ima 542 člana (HUOJ, 2014.) dok je prema nekim procjenama broj profesionalnih komunikatora veći od 2.000 ljudi (Jugo, Borić i Preselj, 2012.). Obrazovne mogućnosti u odnosima s javnošću znatno su povećane, a udruga je uvela proces certifikacije za svoje članove.

Danas odnosi s javnošću imaju veliku prigodu da se usvoje kao značajna disciplina kako na području znanstvenoga istraživanja, tako i na području obrazovanja. Međutim, osim ovih obećavajućih početaka nužno je ostvariti i neke dodatne ciljeve kao što je po- 
kretanje znanstvenih projekata, proširenje kruga kvalificiranih istraživača i profesora, sustavno prikupljanje podataka o primjeni odnosa s javnošću u poslovanju te objavljivanje znanstvenih tekstova i udžbenika (Tkalac, 2003.). Značajan doprinos znanstvenome razvoju područja moguće je ostvariti kroz međunarodne usporedne studije.

\subsection{Europski komunikacijski monitor}

Europski komunikacijski monitor je longitudinalno, europsko, transnacionalno anketno istraživanje u području strateških komunikacija. Provodi se svake godine od 2007. i danas ga prate slična istraživanja na drugim kontinentima. Svake godine istraživanje je usmjereno na trenutačnu praksu i buduće trendove razvoja komunikacijskog menadžmenta i odnosa s javnošću u organizacijama. Organizacije koje obuhvaća su korporacije, nevladine organizacije, vladine organizacije i komunikacijske agencije (ECM, 2015.).

Dosadašnji rezultati ECM-a identificirali su određena strukturalna obilježja komunikacijske profesije u Europi. Primjerice, utjecaj komunikacijskih menadžera na oblikovanje organizacijske strategije sustavno se povećava od početka gospodarske krize u Europi, 2008. godine. Komunikacijski menadžeri svoju poziciju doživljavaju snažnijom no prije krize. Današnja komunikacijska profesija sastavljena je od brojnih sub-disciplina poput korporativnih komunikacija, upravljanja javnim poslovima, korporativne društvene odgovornosti i upravljanja javnim pitanjima. Dodatno, sve je vidljiviji utjecaj društvenih medija, iako još nije sasvim jasno pridonose li oni više informacijskoj ili promocijskoj funkciji u korporacijama (ECM, 2011.).

Analiza rezultata ECM-a pokazala je da percepcija značaja problemskih pitanja u odnosima s javnošću ovisi o spolu, zemlji podrijetla i sektora iz kojega praktičari dolaze (korporativnoga, vladinoga, neprofitnoga ili agencijskoga). U longitudinalnoj analizi rezultata europskih praktičara, kao pet najznačajnijih tema pokazale su se sljedeće: povezivanje poslovnih strategija i poslovanja, uključivanje komunikacija u digitalnu evoluciju i društvene medije, izgradnja i održavanje povjerenja, zadovoljenje potrebe za većom razinom transparentnosti i aktivnim javnostima i zadovoljenje povećane potrebe za brzinom i jačinom protoka informacija. Od navedenih pet problemskih pitanja tri su detaljno istražene $u$ akademskim istraživanjima s područja odnosa s javnošću: povezivanje poslovnih strategija i poslovanja koje je direktno povezano s uključivanjem odnosa s javnošću među strateške funkcije upravljanja (Grunig, 2006; Verčič i Grunig, 2000.), zadovoljenje potrebe za većom razinom transparentnosti i aktivnim javnostima (Grunig, 1992.) i izgradnja i održavanje odnosa povjerenja (Bentele, 2003.; Grunig i Hon, 1999.). Istraživanja usmjerena prema analizi digitalne revolucije i društvenim medijima i prema zadovoljenju povećane potrebe za brzinom i jačinom protoka informacija još uvijek su na začetku (Verčič, Verhoeven i Zerfass, 2014.).

Odnosi s javnošću, prema rezultatima Europskog komunikacijskog monitora iz 2011. godine, povezani su s negativnim konotacijama u većini zemalja. Posebno negativan doživljaj pojma javljaju poljski, britanski, norveški, danski, norveški, srpski, njemački i hrvatski praktičari (grafikon 1.)

U Hrvatskoj se čak 52,3 \% stručnjaka složilo s tvrdnjom: „U mojoj zemlji odnosi s javnošću imaju negativne konotacije u medijima." (na skali od 1 do 5, zaokružili su odgovore 4 ili 5). Time je Hrvatska treća na listi zemalja koji smatraju pojam odnosa s javnošću negativno stereotipiziranim, odmah nakon Poljske i Velike Britanije. Kada je riječ o tvrdnji: „Odnosi s javnošću imaju loš ugled kao profesija“, hrvatski stručnjaci nalaze se na 
neslavnom, prvome mjestu sa 65,8 \% praktičara koji se slažu s tvrdnjom (na skali od 1 do 5, zaokružili su odgovore 4 ili 5).

Grafikon 1. Doživljena reputacija odnosa s javnošću u masovnim medijima

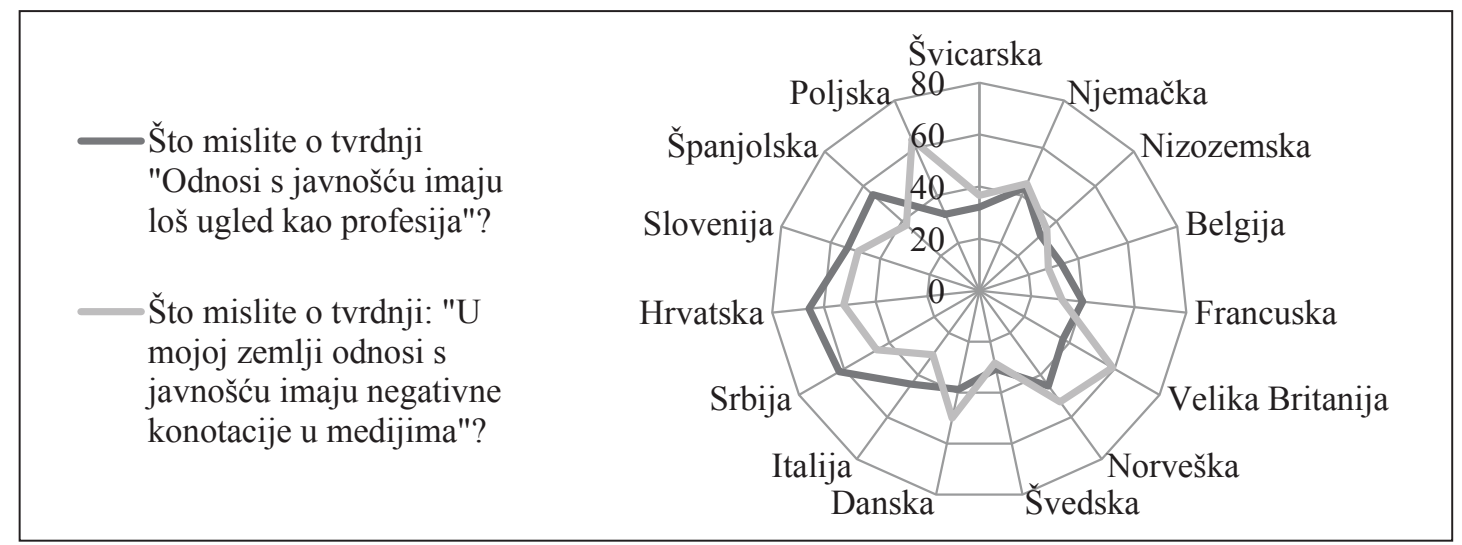

Izvor: prilagođeno prema izvješću ECM, 2011.

Kada je riječ o položaju koji odnosi s javnošću imaju u organizaciji, rezultati ECM-a pokazuju kako komunikacijska funkcija dobiva na značaju (ECM, 2011.). U tri od četiri organizacije komunikatori su uključeni u kreiranje strategije. 17,8 \% komunikacijskih stručnjaka u Europi, dio su upravnoga odbora u svojim organizacijama. Naravno, situacija se značajno razlikuje od zemlje do zemlje. U Hrvatskoj je manje od $4 \%$ ispitanika dio upravnoga odbora. Većina praktičara, njih preko $68 \%$ odgovara izravno predsjedniku upravnoga odbora. $21 \%$ stručnjaka odgovora nekome drugom članu uprave, dok preostalih $6 \%$ ne odgovara nikome u upravnom odboru (grafikon 2).

Grafikon 2. Položaj stručnjaka za odnose s javnošću u organizacijama

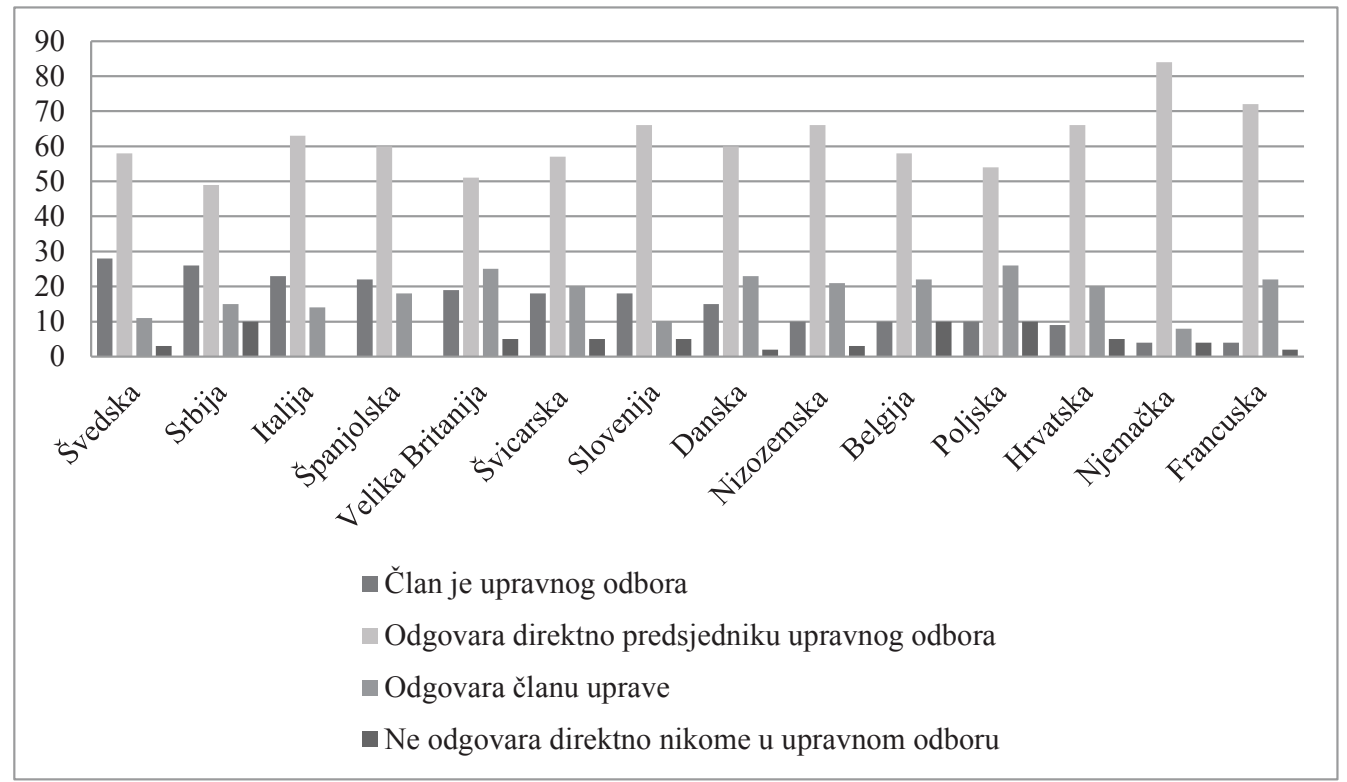

Izvor: prilagođeno prema izvješću ECM, 2011. 
Jedan od značajnih zaključaka ECM-a jest i taj da komunikacijski profesionalci u Europi svoj posao procjenjuju stimulativnim. Svoja iskustva na poslu ocjenjuju stimulativnima i raznolikima $(77,3 \%)$ te smatraju da ih njihovi nadređeni i klijenti cijene $(66,7 \%)$. S druge strane, samo trećina stručnjaka smatra svoju plaću dovoljno velikom $(37,6 \%)$, ravnotežu posla i osobnoga života odgovarajućom (36,3\%) i vidi dovoljno prilika u vlastitoj karijeri (36,1 \%). Većina stručnjaka za odnose s javnošću je ipak zadovoljna svojim poslom $(66,5$ $\%)$. Među hrvatskim stručnjacima odgovor na pitanje o zadovoljstvu poslom nešto je iznad prosjeka (ocjena 3,66 na skali od 1 do 5, prikazano na slici 3.), no ispod smo europskoga prosjeka na tek 14. mjestu od ukupno 20 zemalja.

Grafikon 3. Ocjena zadovoljstva poslom komunikacijskih stručnjaka

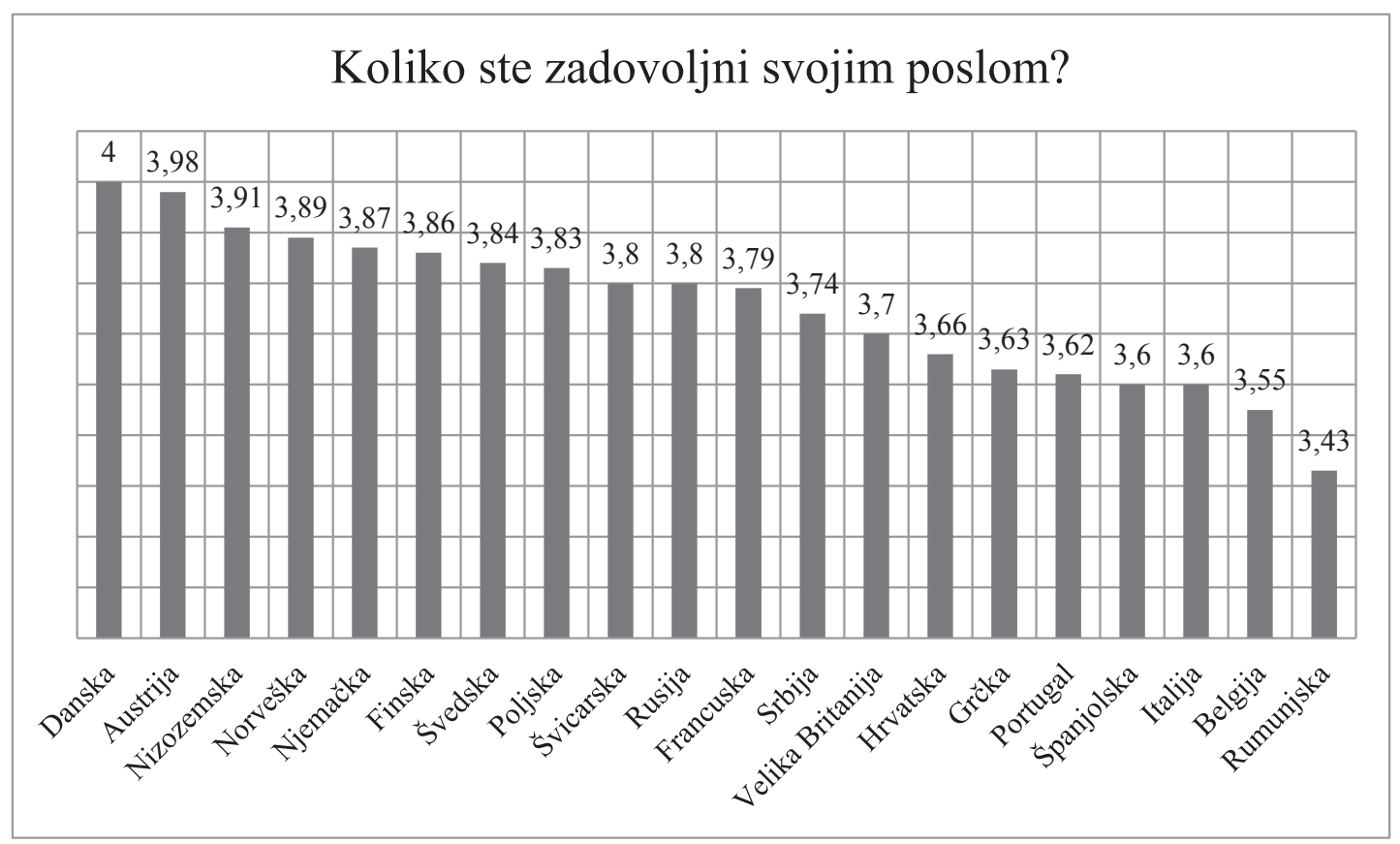

Izvor: prilagođeno prema izvješću ECM, 2011.

U Europskom komunikacijskom monitoru provedenome 2014. godine, stručnjake se pitalo kolika je važnost pojedinih problemskih tema u odnosima s javnošću (odnosno, preciznije, koje su od tema značajne za praksu odnosa s javnošću u njihovim zemljama). Među najvažnijim pitanjima bila su sljedeća: pojašnjavanje pozitivnih efekata dobre reputacije na organizacijsku kulturu, ilustriranje koristi od slušanja dionika i identifikacije mogućnosti, pojašnjavanje uloge vodstva u znanju za ostvarenje organizacijskih ciljeva, demonstriranje pozitivnih ekonomskih učinaka i ukazivanje na potražnju za komunikacijom i transparentnošću. Hrvatski stručnjaci najmanje su značaja pridali pojašnjavanju uloge vodstva u znanju za ostvarenje organizacijskih ciljeva (samo $50 \%$ stručnjaka označilo je ovu temu značajnom). Demonstriranje pozitivnih ekonomskih učinaka i ukazivanje na potražnju za komunikacijom i transparentnošću dobili su nešto veću ocjenu značaja (52,2 \% i 54,3 \%). Najznačajnijom temom procijenjeno je pojašnjavanje pozitivnih efekata dobre reputacije na organizacijsku kulturu (čak 71,7 \% stručnjaka označilo je ovu temu kao značajnu). No, 
i s takvom ocjenom hrvatski su komunikacijski stručnjaci ovoj temi dali gotovo najmanju ocjenu među europskim komunikatorima. Upravo ove razlike navode na pitanje kolike su razlike u osnovnim procjenama pojedinih europskih stručnjaka za odnose s javnošću i kako se hrvatski stručnjaci smještaju u taj kontekst. Stoga je ključni problem odnosno istraživačko pitanje ovoga rada - postoji li značajna razlika u procjeni važnosti problemskih pitanja među hrvatskim i europskim stručnjacima za odnose s javnošću?

Tablica 1. Prikaz postotka stručnjaka koji su pojedinu od navedenih tema procijenili značajnom

\begin{tabular}{|l|c|c|c|c|c|}
\hline & $\begin{array}{c}\text { Pojašnjavanje } \\
\text { pozitivnih } \\
\text { efekata dobre } \\
\text { reputacije na } \\
\text { organizacijsku } \\
\text { kulturu }\end{array}$ & $\begin{array}{c}\text { Ilustriranje } \\
\text { koristi od } \\
\text { slušanja } \\
\text { dionika i } \\
\text { identifikacije } \\
\text { mogućnosti }\end{array}$ & $\begin{array}{c}\text { Pojašnjavanje } \\
\text { uloge vodstva } \\
\text { u znanju za } \\
\text { ostvarenje } \\
\text { organizacijskih } \\
\text { ciljeva }\end{array}$ & $\begin{array}{c}\text { Demonstriranje } \\
\text { pozitivnih } \\
\text { ekonomskih } \\
\text { učinaka }\end{array}$ & $\begin{array}{c}\text { Ukazivanje na } \\
\text { potražnju za } \\
\text { komunikacijom i } \\
\text { transparentnošću }\end{array}$ \\
\hline Njemačka & 77,1 & 57,8 & 64,2 & 55 & 31,2 \\
\hline Austrija & 82,1 & 64,3 & 50 & 53,6 & 39,3 \\
\hline Švicarska & 86,5 & 61,5 & 57,7 & 48,1 & 42,3 \\
\hline Francuska & 76,9 & 57,7 & 61,5 & 53,8 & 46,2 \\
\hline Belgija & 76,9 & 73,1 & 80,8 & 57,7 & 57,7 \\
\hline Nizozemska & 82,2 & 57,8 & 57,8 & 42,2 & 26,7 \\
\hline Vel. Britanija & 90,6 & 60,4 & 54,7 & 66 & 35,8 \\
\hline Irska & 68,8 & 62,5 & 43,8 & 56,3 & 50 \\
\hline Danska & 83,3 & 62,5 & 37,5 & 66,7 & 41,7 \\
\hline Švedska & 66,7 & 48,5 & 57,6 & 45,5 & 54,5 \\
\hline Norveška & 73,7 & 57,9 & 31,6 & 57,9 & 42,1 \\
\hline Finska & 86,2 & 62,1 & 62,1 & 69 & 44,8 \\
\hline Španjolska & 75,5 & 53,1 & 51 & 73,5 & 53,1 \\
\hline Portugal & 77,8 & 77,8 & 55,6 & 48,1 & 66,7 \\
\hline Italija & 83,1 & 69,2 & 50,8 & 58,5 & 41,5 \\
\hline Slovenija & 73,3 & 53,3 & 64,4 & 66,7 & 51,1 \\
\hline Hrvatska & 71,7 & 58,7 & 50 & 52,2 & 54,3 \\
\hline Turska & 91,3 & 65,2 & 69,6 & 60,9 & 56,5 \\
\hline Rumunjska & 81 & 65,5 & 62,1 & 77,6 & 56,9 \\
\hline Ukrajina & 80,6 & 55,6 & 62,1 & 50 & 66,7 \\
\hline
\end{tabular}

Izvor: prilagođeno prema izvješću ECM, 2014.

\section{METODOLOGIJA ISTRAŽIVANJA}

Kako bi se odgovorilo na istraživačko pitanje, provedena je sekundarna analiza na podacima prikupljenima longitudinalnim istraživanjem od 2007. do 2015. godine. Analiza je ponajprije namijenjena istraživanju potencijalne razlike u percepciji hrvatskih i ostalih europskih komunikacijskih stručnjaka o značaju pojedinih problemskih pitanja za praksu odnosa s javnošću. Podaci Europskog komunikacijskog monitora posebno su pogodni za ovakvu analizu, s obzirom da osnovni ciljevi istraživanja obuhvaćaju praćenje trendova u komunikacijskom menadžmentu, analizu promjene u obrascima komunikacijske profesije 
u Europi, evaluaciju specifičnih tema u profesiji i identifikaciju razvoja kroz različite tipove organizacija, zemalja i regija Europe. Istraživanje obuhvaća ispitivanje demografskih obilježja stručnjaka za odnose s javnošću, strukturu i kulturu organizacija u kojima rade, opis komunikacijske funkcije koju obnašaju, trenutačnu komunikacijsku situaciju organizacije (onu u kojoj se nalazi u trenutku istraživanja) i percepciju najvažnijih trendova, izazova i problemskih pitanja u struci.

\subsection{Postupak i uzorak}

Europski komunikacijski monitor provodi se anketnim istraživanjem na internetu, na engleskome jeziku. Prikupljanje podataka svake godine započinje u proljeće i traje četiri tjedna. Poziv na sudjelovanje u istraživanju šalje se na više od 20.000 elektroničkih adresa (prikupljenih putem nacionalnih udruženja, mreža stručnjaka i baze podataka ECM-a). U Hrvatskoj poziv na istraživanje upućuje Hrvatska udruga za odnose s javnošću svim svojim članovima. U cijeloj Europi dosada (od 2007. godine) prikupljeno 16.310 upitnika, s prosjekom od 2.039 godišnje dok je u Hrvatskoj dosada prikupljeno 550 upitnika, s prosjekom od 61 upitnika godišnje. Kako je ispunjavanje upitnika anonimno, nije moguće odrediti koliki dio ispitanika je ponovljen. Osnovna demografska obilježja hrvatskih ispitanika prikazana su u tablici 2.

\subsection{Pitanja i analiza}

U svakome provedenom valu analize (od 2007. do 2015. godine) od ispitanika se tražilo da ocijene najvažnija strateška pitanja iz njihove perspektive. Svake je godine postavljeno isto pitanje koje je glasilo: „Navedena su određena strateška pitanja koja bi mogla postati značajna za odnose s javnošću i komunikacijski menadžment u sljedeće tri godine, molimo vas da označite ona tri koja se vama čine najznačajnijima.“

Strateška pitanja identificirana su i uključena nakon detaljne analize literature. U 2012. godini sastavljena je nova lista strateških pitanja temeljena na empirijskim rezultatima prethodnih godina provođenja Europskog komunikacijskog monitora te dodatne analize literature. U tablici 3. prikazan je pregled strateških pitanja uključenih u istraživanje. 
Tablica 2. Demografska obilježja hrvatskih ispitanika u ECM istraživanju od 2007. do 2015.

\begin{tabular}{|c|c|c|c|c|c|c|c|c|c|c|}
\hline Godina & & 2007. & 2008. & 2009. & 2010. & 2011. & 2012. & 2013. & 2014. & 2015. \\
\hline Veličina uzorka & & 4 & 60 & 36 & 38 & 111 & 61 & 58 & 70 & 112 \\
\hline \multicolumn{11}{|l|}{ Spol } \\
\hline & Muški & - & 13 & 10 & 12 & 34 & 21 & 21 & 16 & 30 \\
\hline & Ženski & - & 47 & 26 & 26 & 77 & 40 & 37 & 54 & 82 \\
\hline Prosječna dob & & 52 & 45 & 41 & 40 & 44 & 44 & 38 & 43 & 47 \\
\hline $\begin{array}{l}\text { Više od } 10 \text { godina } \\
\text { radnog iskustva }\end{array}$ & & 3 & 11 & 8 & 9 & 31 & 27 & 31 & 31 & 56 \\
\hline \multicolumn{11}{|l|}{ Vrsta organizacije } \\
\hline & Dioničko društvo & - & - & 15 & 11 & 24 & 15 & 12 & 10 & 23 \\
\hline & Privatna & - & - & 6 & 11 & 19 & 17 & 16 & 10 & 23 \\
\hline & $\begin{array}{l}\text { U državnom } \\
\text { vlasništvu }\end{array}$ & - & - & 3 & 3 & 21 & 12 & 9 & 20 & 22 \\
\hline & Neprofitna & - & - & 1 & & 3 & 2 & 1 & 5 & 9 \\
\hline & Agencija & - & - & 11 & 13 & 44 & 15 & 20 & 25 & 35 \\
\hline \multicolumn{11}{|l|}{ Položaj } \\
\hline & Direktor & - & - & 12 & 14 & 47 & 29 & 24 & 21 & 49 \\
\hline & $\begin{array}{l}\text { Odgovoran/a za } \\
\text { funkciju }\end{array}$ & - & - & 15 & 12 & 28 & 13 & 13 & 16 & 23 \\
\hline & Konzultant & - & - & 6 & 11 & 25 & 13 & 16 & 23 & 29 \\
\hline & Drugo & - & - & 3 & 1 & 11 & 6 & 5 & 60 & 101 \\
\hline \multicolumn{11}{|l|}{ Obrazovna razina } \\
\hline & Doktorat & - & - & 1 & 0 & 3 & 1 & 2 & 2 & 3 \\
\hline & Magisterij & - & - & 24 & 22 & 67 & 45 & 39 & 55 & 82 \\
\hline & Diploma & - & - & 11 & 15 & 36 & 14 & 15 & 12 & 21 \\
\hline & $\begin{array}{l}\text { Bez akademskog } \\
\text { stupnja }\end{array}$ & - & - & 0 & 1 & 5 & 1 & 2 & 1 & 6 \\
\hline
\end{tabular}

Izvor: istraživanje.

\section{REZULTATI I RASPRAVA}

Usporedna analiza procjena važnosti strateških pitanja europskih i hrvatskih stručnjaka daje određen uvid u način na koji se domaći praktičari uklapaju u europske trendove. Podaci prikazani u tablici 3. pokazuju da se među europskim praktičarima konzistentno najvažnijima pokazuju četiri strateška pitanja. Dva najznačajnija su povezivanje poslovne strategije i komunikacija (45 \%) i uključivanje u digitalnu evoluciju i društvene mreže (45 $\%)$. Navedena dva pitanja slijede izgradnja i održavanje povjerenja (35\%) i potreba za većom transparentnošću i aktivnim javnostima (31 \%). U 2014. godini novo strateško pitanje s visokih $34 \%$ postaje i upravljanje brzinom i jačinom tijeka informacija.

Kada je riječ o hrvatskim stručnjacima pregled najznačajnijih strateških pitanja ukazuje da najveći izazovi također predstavljaju povezivanje ukupnoga poslovanja s komunikacijom te izgradnja i održavanje povjerenja u poslovanje organizacije u digitalno doba. Takvi su rezultati očekivani u vrijeme u kojemu aktivne javnosti imaju vlastite društvene medije, traže transparentnost i proizvode ogromne količine informacija velikom brzinom. 
Tablica 3. Popis strateških pitanja s postotcima važnosti koje im pridaju komunikacijski stručnjaci u Hrvatskoj i Europi*

\begin{tabular}{|c|c|c|c|c|c|c|c|c|c|}
\hline & 2007. & 2008. & 2009. & 2010. & 2011. & 2012. & 2013. & 2014. & 2015. \\
\hline Povezivanje poslovne strategije i komunikacija & $50(45)$ & $43(47)$ & $56(44)$ & $53(44)$ & $41(44)$ & $53(43)$ & $40(45)$ & $41(45)$ & 30 \\
\hline $\begin{array}{l}\text { Uključivanje u digitalnu evoluciju i društvene } \\
\text { mreže }\end{array}$ & $25(39)$ & $33(45)$ & $42(54)$ & $47(55)$ & $52(46)$ & $47(42)$ & $41(32)$ & $27(45)$ & 39 \\
\hline Izgradnja i održavanje povjerenja & $25(30)$ & $33(35)$ & $36(33)$ & $26(30)$ & $25(32)$ & $26(38)$ & $40(39)$ & $36(35)$ & 31 \\
\hline $\begin{array}{l}\text { Upravljanje povećanom potražnjom za većom } \\
\text { transparentnošću i aktivnijom publikom }\end{array}$ & $25(29)$ & $27(31)$ & $33(33)$ & $16(35)$ & $33(23)$ & $16(29)$ & $21(28)$ & $26(31)$ & 22 \\
\hline $\begin{array}{l}\text { Upravljanje brzinom i intenzitetom protoka } \\
\text { informacija }\end{array}$ & & & & & & & & $27(34)$ & 26 \\
\hline $\begin{array}{l}\text { Odgovaranje na potrebu za komunikaciju } \\
\text { s povećanim brojem javnosti i kanala s } \\
\text { ograničenim resursima }\end{array}$ & - & - & - & - & - & $28(35)$ & $33(31)$ & $24(33)$ & 31 \\
\hline $\begin{array}{l}\text { Povećana uloga komunikacijske funkcije u } \\
\text { podržavanju odluka menadžmenta }\end{array}$ & & & & - & & $36(33)$ & $41(29)$ & $37(32)$ & 39 \\
\hline $\begin{array}{l}\text { Upravljanje održivim razvojem i društvenom } \\
\text { odgovornošću }\end{array}$ & $50(41)$ & $53(38)$ & $33(37)$ & $40(37)$ & $47(21)$ & $40(22)$ & $24(16)$ & $24(30)$ & 21 \\
\hline Podržavanje organizacijskih promjena & $25(17)$ & $13(20)$ & $17(21)$ & $16(19)$ & $15(22)$ & $16(26)$ & $22(22)$ & $21(21)$ & \\
\hline $\begin{array}{l}\text { Uspostavljanje novih metoda za evaluaciju } \\
\text { komunikacije }\end{array}$ & $25(16)$ & $28(19)$ & $28(17)$ & $24(18)$ & 32 & 24 & & (20) & \\
\hline $\begin{array}{l}\text { Razvijanje odnosa s novim vratarima } \\
\text { i javnostima i reagiranje na njihove } \\
\text { komunikacijske potrebe }\end{array}$ & - & - & - & - & - & - & $22(19)$ & & \\
\hline Globalizacija komunikacije & - & $22(24)$ & $14(17)$ & $18(15)$ & $14(17)$ & $18(18)$ & - & - & \\
\hline Stimuliranje i promocija inovacija & $25(18)$ & & . & - & - & - & - & & \\
\hline $\begin{array}{l}\text { Unapređenje javnih poslova i političke } \\
\text { komunikacije }\end{array}$ & $25(15)$ & $23(15)$ & $14(12)$ & $18(13)$ & $18(-)$ & $18(-)$ & & (18) & \\
\hline $\begin{array}{l}\text { Redefiniranje odnosa između marketinga i } \\
\text { korporativnih komunikacija }\end{array}$ & - & & & - & - (16) & - & - & (16) & \\
\hline $\begin{array}{l}\text { Pojačano slušanje i praćenje internih i } \\
\text { eksternih kapaciteta }\end{array}$ & & & & & $-(15)$ & - & & (15) & \\
\hline $\begin{array}{l}\text { Unapređenje upravljanja problemskim } \\
\text { pitanjima }\end{array}$ & - & $8(15)$ & $19(15)$ & $24(12)$ & $13(13)$ & 24 & & (14) & \\
\hline $\begin{array}{l}\text { Pozicioniranje organizacija kao vodećih u } \\
\text { svom području }\end{array}$ & - & & & - & - & - & - (14) & $23(14)$ & \\
\hline $\begin{array}{l}\text { Razvoj organizacijskih struktura za koordinirane } \\
\text { komunikacijske aktivnosti u različitim zemljama } \\
\text { i među različitim dionicima }\end{array}$ & - & & & - & - (13) & - & - & (13) & \\
\hline Pozicioniranje predsjednika uprave & - & $7(10)$ & $8(11)$ & $13(11)$ & $9(-)$ & $13(-)$ & - & $(11)$ & \\
\hline $\begin{array}{l}\text { Unapređenje međunarodnih i interkulturalnih } \\
\text { komunikacija }\end{array}$ & & & & & & - & $10(11)$ & (11) & \\
\hline Prikaz predsjednika i članova uprave kao vodstva & - & - & - & - & - & - & - (10) & $11(10)$ & \\
\hline Integracija odnosa s javnošću i s investitorima & $25(8)$ & - & 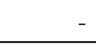 & - & - & - & - & (8) & \\
\hline Podrška interkulturalnoj integraciji & - & $8(9)$ & $0(6)$ & $5(6)$ & $2(6)$ & $5(-)$ & - & (7) & \\
\hline $\begin{array}{l}\text { Odgovaranje na izazove generiranja podataka, } \\
\text { njihove pohrane i korištenja }\end{array}$ & & & & & $-(5)$ & & 5 & (5) & \\
\hline
\end{tabular}

Izvor: istraživanje.

*U tablici je prikazan postotak hrvatskih komunikacijskih stručnjaka koji su pojedinu temu odabrali kao jednu od tri najznačajnije. U zagradama su prikazani odgovori europskih stručnjaka. 
Među europskim stručnjacima, druga značajna skupina strateških pitanja (više od $30 \%$ ) jest zadovoljenje potrebe za komunikacijom sa sve većim brojem javnosti i smanjivanja resursa, nakon čega slijedi pojačanje uloge komunikacijske funkcije u podržavanju strateškoga menadžmenta ( $32 \%$ ) i pomoć u upravljanju održivim razvojem i društvenom odgovornošću (30 \%). Održivi razvoj i društvena odgovornost postupno gube na značaju, s visokim rezultatima do 2011. godine. Od 2012. godine ograničeni resursi i podržavanje uprave preuzimaju važniju ulogu. U Hrvatskoj se zadovoljenje potrebe za komunikacijom pokazuje kao relativno značajna tema iako s nešto manjim postotkom značaja. Za razliku od toga, povećanje uloge komunikacijske funkcije u podržavanju strateškoga menadžmenta sustavno se procjenjuje još i značajnijim no među europskim kolegama. Pomoć u upravljanju održivim razvojem i društvenom odgovornošću među hrvatskim se stručnjacima sustavno procjenjuje znatno višim postocima značaja, no među europskim komunikatorima (u svim godinama, osim 2009.), no također se slijedi trend europskih kolega i ovo problemsko pitanje svake godine gubi na značaju.

Treća skupina strateških pitanja povezana je sa širokim spektrom tema poput uvođenja novih evaluacijskih metoda (20\% u prosjeku), podržavanje organizacijskih promjena (19\%), povezivanje s novim vratarima i javnostima i odgovaranje na njihove komunikacijske potrebe (19\%), globalizacija komunikacije (18\%) i unapređenje političke komunikacije (18\%). U procjenama ovih tema, hrvatski stručnjaci razlikuju se djelomično od svojih europskih kolega. Provedbom hi-kvadrat testa u tablici 4. prikazane su značajne razlike u procjenama važnosti problemskih tema među hrvatskim i europskim stručnjacima, po godinama.

Pregledom tema i uvidom u razlike koje se pojavljuju među hrvatskim i europskim stručnjacima vidljivo je nekoliko ključnih područja neslaganja u procjenama. U procjenama povezivanja poslovne strategije i komunikacija razlike su se pokazale u tri godine - 2009., 2010. i 2012. U svakoj od navedenih godina hrvatski su stručnjaci za odnose s javnošću procijenili ovu temu značajno važnijom, no što su to učinili europski komunikatori. Vidljivo je, međutim, da su se tijekom posljednjih godina procjene hrvatskih komunikatora spustile na razinu europskih. U Hrvatskoj je profesija odnosa s javnošću relativno mlada (odnosno mlađa no u većini ostalih zemalja unutar kojih se provodi istraživanje), pa ne iznenađuje potreba za dokazivanjem važnosti područja. Razvojem područja, potreba za dokazivanjem sve je manja (iako trajno jedno od najznačajnijih problemskih pitanja).

Uključivanje u digitalnu evoluciju i društvene mreže u Hrvatskoj se pet puta pokazalo značajno manje važnim no u ostalim europskim zemljama. U 2007., 2008., 2009. i 2014. godini hrvatski su komunikatori ocijenili da je važnost digitalizacije odnosa s javnošću manje važna od serije drugih tema, dok su europski stručnjaci ovu temu većinu godina stavili na drugo mjesto po značaju. Iako se i među hrvatskim stručnjacima činilo da je ova tema svake godine procijenjena sve značajnijom, u 2014. godini, samo je 27 posto hrvatskih ispitanika ovo procijenilo značajnim.

Još jedna tema u kojoj se nekoliko godina za redom procjena hrvatskih stručnjaka pokazala značajno drugačijom od europskih kolega jest upravljanje povećanom potražnjom za većom transparentnošću i aktivnijom publikom. No, zanimljivo, u 2010. i 2012. hrvatski komunikatori dali su ovoj temi manji značaj od europskih stručnjaka za odnose s javnošću, no u 2011., istoj su temi pripisali veći značaj od europskih kolega. Kada je riječ o upravljanju održivim razvojem i društvenom odgovornošću, hrvatski stručnjaci za odnose s javnošću procjenjuju ovu temu značajno važnijom od ostalih europskih stručnjaka i ta razlika se u 2011. i 2012. pokazala statistički značajnom. 
Tablica 4. Prikaz značajnih razlika u procjenama važnosti (u postotcima) problemskih pitanja dobivenih $\chi^{2}$ testom

\begin{tabular}{|c|c|c|c|c|c|c|c|}
\hline Problemsko pitanje & Godina & HR & $\mathbf{E U}$ & SS & $\mathbf{n}$ & $\chi^{2}$ & $\begin{array}{l}\text { Značajnost } \\
\text { razlike }\end{array}$ \\
\hline \multirow[t]{3}{*}{$\begin{array}{l}\text { Povezivanje poslovne strategije i } \\
\text { komunikacija }\end{array}$} & 2009. & 56 & 44 & 1 & 1863 & 12.202 & 0.05 \\
\hline & 2010. & 53 & 44 & 1 & 1955 & & 0.05 \\
\hline & 2012. & 53 & 43 & 1 & 2185 & & 0.05 \\
\hline \multirow[t]{4}{*}{$\begin{array}{l}\text { Uključivanje u digitalnu evoluciju i } \\
\text { društvene mreže }\end{array}$} & 2007. & 25 & 39 & 1 & 1075 & & 0.01 \\
\hline & 2008. & 33 & 45 & 1 & 1524 & & 0.05 \\
\hline & 2009. & 42 & 54 & 1 & 1863 & & 0.05 \\
\hline & 2014. & 27 & 45 & 1 & 2777 & & 0.01 \\
\hline Izgradnja i održavanje povjerenja & 2012. & 26 & 38 & 1 & 2185 & & 0.01 \\
\hline \multirow{3}{*}{$\begin{array}{l}\text { Upravljanje povećanom potražnjom } \\
\text { za većom transparentnošću i } \\
\text { aktivnijom publikom }\end{array}$} & 2010 . & 16 & 35 & 1 & 1955 & & 0.01 \\
\hline & 2011. & 33 & 23 & 1 & 2209 & & 0.05 \\
\hline & 2012. & 16 & 29 & 1 & 2185 & & 0.01 \\
\hline $\begin{array}{l}\text { Povećana uloga komunikacijske } \\
\text { funkcije u podržavanju odluka } \\
\text { menadžmenta }\end{array}$ & 2013. & 41 & 29 & 1 & 2710 & & 0.05 \\
\hline \multirow[t]{2}{*}{$\begin{array}{l}\text { Upravljanje održivim razvojem i } \\
\text { društvenom odgovornošću }\end{array}$} & 2011. & 47 & 21 & 1 & 2209 & & 0.01 \\
\hline & 2012. & 40 & 22 & 1 & 2185 & & 0.01 \\
\hline $\begin{array}{l}\text { Podržavanje organizacijskih } \\
\text { promjena }\end{array}$ & 2012. & 16 & 26 & 1 & 2185 & & 0.01 \\
\hline $\begin{array}{l}\text { Uspostavljanje novih metoda za } \\
\text { evaluaciju komunikacije }\end{array}$ & 2009. & 28 & 17 & 1 & 1863 & & 0.05 \\
\hline $\begin{array}{l}\text { Unapređenje upravljanja } \\
\text { problemskim pitanjima }\end{array}$ & 2010. & 24 & 12 & 1 & 1955 & & 0.01 \\
\hline
\end{tabular}

Izvor: istraživanje.

U nekim od preostalih pitanja postoje razlike, no one se značajnima pokazuju samo u po jednoj godini. Primjerice, izgradnja i održavanje povjerenja u 2012. (manje važno hrvatskim, no europskim stručnjacima), povećana uloga komunikacijske funkcije u podržavanju odluka menadžmenta u 2013. (važnije hrvatskim, no europskim stručnjacima), podržavanje organizacijskih promjena u 2012. (manje važno hrvatskim, no europskim stručnjacima), uspostavljanje novih metoda za evaluaciju komunikacije u 2009. (važnije hrvatskim, no europskim stručnjacima) i unapređenje upravljanja problemskim pitanjima u 2010. godini (važnije hrvatskim, no europskim stručnjacima).

Longitudinalna analiza podataka prikupljenih Europskim komunikacijskim monitorom ukazuje da se potreba za transparentnošću i aktivnim javnostima konzistentno po- 
kazuje značajnijom u sjevernoj i zapadnoj Europi, no u istočnoj i južnoj Europi (Verčič i sur., 2014.). Taj trend potvrđen je i kada je riječ o hrvatskim stručnjacima koji u gotovo svim mjerenjima iskazuju manji stupanj značaja ovoga problemskog pitanja. Slični rezultati mogu se vidjeti i kada je riječ o digitalnoj evoluciji i društvenim mrežama. Nasuprot tome, pitanja održivoga razvoja i društvene odgovornosti u južnoj i istočnoj Europi značajnije su procijenjena, no u sjevernoj i zapadnoj Europi (Verčič i sur., 2014.). Hrvatska se i ovdje potpuno uklapa u svoju regiju (južna Europa). Objašnjenje za otkrivene razlike u procjeni važnosti pojedinih problemskih pitanja je dvojako. Prije svega, čini se da nešto mlađa struka odnosa s javnošću u Hrvatskoj, još uvijek hvata korak s europskim kolegama. Pitanja poput uklapanja u digitalnu evoluciju ili povećane potrebe za transparentnošću još uvijek nisu postala prioritet, obzirom na druge, veće probleme u razvoju same struke. Važnije je, prvo, upravama organizacija pojasniti korist komunikacijske funkcije. Drugo, kulturološki okvir značajno oblikuje vrijednosne sustave praktičara i time snažno djeluje na izrazito lokalne profesije poput odnosa s javnošću. Hrvatski praktičari sa susjedima dijele procjenu važnosti ključnih pitanja u razvoju struke odnosa s javnošću. Ovakav zaključak dodatno podvlači važnost lokalnog razvoja profesije, no i razmjene znanja i iskustava s kolegama svugdje u Europi (i šire). Na taj način globalna znanja pomažu u razvoju hrvatske struke, no s posebnom prilagodbom lokalnim posebnostima.

\section{ZAKLJUČAK}

Neupitno je da su odnosi s javnošću profesija koja je pod značajnim utjecajem lokalnih političkih, kulturoloških i gospodarskih trendova. Zato je važno odrediti koji dio profesionalnih vrijednosti u ovome području ima globalan značaj, a koja su problemska pitanja lokalno specifična. Za utvrđivanje položaja hrvatskih komunikacijskih praktičara analizirani su podaci Europskog komunikacijskog monitora i provedena je usporedna analiza longitudinalnih podataka procjena hrvatskih praktičara u usporedbi s europskim.

Ključno ograničenje provedene analize jest relativno mali uzorak hrvatskih praktičara u početnim godinama provođenja istraživanja. Rezultati su zato analizirani neparametrijskim statističkim postupkom i zaključci služe kao početni indikator za uvid u stanje. Vidljivo je da se procjena važnosti hrvatskih stručnjaka donekle razlikuje od procjene europskih komunikatora. Takvi rezultati potvrđuju tezu o lokalnoj specifičnosti odnosa s javnošću i naglašavaju važnost lokalnoga razvoja znanja i vještina, uz korištenje globalnih teorija i koncepata.

\section{LITERATURA:}

1. Bentele, Ghunter (2003.) Public trust: Theory and empirical results in Germany. Paper presented to the 10th International Public Relations Research Symposium, BledCom 2003. 4-6 July, Bled, Slovenia.

2. Carlson, Robert (1968.) Public Relations u D. L. Sills (ur.) International encyclopedia of the social sciences (str. 208 -216), London: Macmillan.

3. Coombs, Timothy, Holladay, Sherry, Hasenauer, Gabriele i Signitzer, Benno (1994.) A comparative analysis of international public relations: Identification and interpre- 
tation of similarities and differences between professionalization in Austria, Norway, and the United States. Journal of Public Relations Research, 6, 23-39.

4. Golob, Urša i Bartlett, Jennifer (2007.) Communicating about corporate social responsibility: A comparative study of CSR reporting in Australia and Slovenia. Public Relations Review 3 (1), 1-9.

5. Grunig, James i Hon, Linda (1999.) Guidelines for measuring relationships in public relations. Gainesville, FL: Institute for Public Relations, Commission on PR Measurement and Evaluation.

6. Grunig, Lauri (1992.) Activism: How it limits the effectiveness of organizations and how excellent public relations departments respond. In J. E. Grunig (Ed.), Excellence in public relations and communication management (503-530). Hillsdale, NY: Lawrence Erlbaum Associates.

7. Grunig, James (2006.). Furnishing the edifice: Ongoing research on public relations as a strategic management function. Journal Of Public Relations Research, 18, 151176.

8. Hajoš, Boris i Tkalac, Ana (2004.) Croatia. In B. van Ruler \& D. Verčič (Eds.), Public relations and communications management in europe: A nation by nation introduction to public relations theory and practice (pp. 83-94). New York: Mouton de Gruyter.

9. Hajoš, Boris (2002.) Public relations scene in Croatia. BledCom 2002, the 9th International Public Relations Research Symposium, 4 - 7 July, Bled, Slovenia.

10. HUOJ (2014.) http://www.huoj.hr/o-huoj-u/clanstvo-hr4, 6. 2. 2014.

11. Jugo, Damir, Borić, Stanko i Preselj, Vladimir (2012.) Analiza razvoja odnosa s javnošću u Hrvatskoj od 2003. do 2009. i projekcija budućih trendova. Međunarodne studije, 12(3/4), 37-52.

12. McManus, Tim (1994.) A comparative analysis of public relations in Austria and the United Kingdom. Paper presented to the International Public Relations Research Symposium, Bled, Slovenia.

13. Moreno, Àngeles, Zerfass, Ansgar, Tench, Ralph, Verčič, Dejan i Verhoeven Piet (2009.) European Communication Monitor current developments, issues and tendencies of the professional practice of public relations in Europe, Public Relations Review, 35 (1), 79-82.

14. Nessmann, Karl (1995.) Public relations in Europe: A comparisont with the United States. Public Relations Review, 21(2), 151-160.

15. Petrović, Mario, Tepeš, Iva i Žigić, Ivica (2014.) Analysis of the public relations agencies market in Croatia and prediction of its future in the European Union, Proceedings of the 2nd International OFEL Conference on Governance, Management and Entrepreneurship, 4th - 5th April, 2014, Dubrovnik, Croatia.

16. Sriramesh, Krishnamurti i White, John (1992.) Societal culture and public relations, in James E. Grunig (ed.), Excellence in public Relations and Communication Management. Hillsdale, NJ: Lawrence Erlbaum Associates, 597-616.

17. Tedlow, Richard (1979.) Keeping the corporate image: Public relations and business 1900 - 1950. Greenwhich, CT Stoffels, J. (1994.). Strategic issue management: A comprehensive guide to environmental scanning. Tarrytown; New York; Elsevier. 
18. Tkalac Verčič, Ana (2016.) Odnosi s javnošću. HUOJ: Zagreb (u tisku).

19. Tkalac, Ana (2003.) Neobjavljena doktorska disertacija. Ekonomski fakultet Zagreb.

20. van Ruler, Betteke i Verčič, Dejan (2008.) Communication management in Europe: Challenges and opportunities. In A. Zerfass (Ed.), Public relations research: European and international perspectives and innovations (313-324). Wiesbaden: VS Verlag für Sozialwissenschalen.

21. Verčič, Dejan i Grunig, James (2000.) The origins of public relations theory in economics and strategic management. In D. Moss, D. Verčič \& G. Warnaby (Eds.), Perspectives on public relations research (9-58). London, UK: Routledge.

22. Verčič, Dejan, Grunig Larissa i Grunig, James (1996.) Global and specific principles of public relations: Evidence from Slovenia. In H. M. Culbertson \& N. Chen (Eds.), International public relations: A comparative analysis (31-66). Mahwah, NY: Lawrence Erlbaum Associates.

23. Verčič, Dejan, Verhoeven, Piet i Zerfass, Ansgar (2014.) Key issues of public relations of Europe: Findings from the European Communication Monitor 2007-2014. Revista Internacional De Relaciones Públicas, 8(IV), 5-26.

24. Wilcox, Dennis, Ault, Phillip i Agee, Warren (1989.) Public Relations: Strategies and tactics. New York: Harper and Row.

25. Zerfass, Ansgar, Tench, Ralph, Verčič, Dejan, Verhoeven, Piet i Moreno, Ángeles (2014.) European communication monitor 2014. Excellence in strategic communication - Key issues, leadership, gender and mobile media. Results of a survey in 42 countries. Brussels: EACD/EUPRERA, Helios Media.

26. Zerfass, Ansgar, Verhoeven, Piet, Tench, Ralph, Moreno, Angeles i Verčič, Dejan (2011.) European Communication Monitor 2011. Empirical insights into strategic communication in Europe. Results of an empirical survey in 43 countries, Brussels, EACD, Euprera. 